\title{
Ergonomics as Authoritarian or Libertarian: Learning from Colin Ward's Politics of Design
}

Carole Boudeau

The Health and Care Infrastructure Research and Innovation Centre (HaCIRIC), School of Construction Management and Engineering, University of Reading, UK

Peter Wilkin

School of Social Science, Brunel University, UK

Sidney W. A. Dekker

School of Humanities, Griffith University,

Brisbane, Australia

ABSTRACT Ergonomics is intrinsically connected to political debates about the good society, about how we should live. This article follows the ideas of Colin Ward by setting the practices of ergonomics and design along a spectrum between more libertarian approaches and more 
authoritarian. Within Anglo-American ergonomics, more authoritarian approaches tend to prevail, often against the wishes of designers who have had to fight with their employers for best possible design outcomes. The article draws on debates about the design and manufacturing of schoolchildren's furniture. Ergonomics would benefit from embracing these issues to stimulate a broader discourse amongst its practitioners about how to be open to new disciplines, particularly those in the social sciences.

KEYWORDS: design, ergonomics, libertarian politics, authoritarian politics, Colin Ward

\section{Introduction}

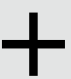

A widening debate has been taking place in ergonomics on the relationship between ergonomics and politics (e.g. Badham et al, 2001; Dekker, 2011a; Fry, 2011Garretty, 2004; Hancock and Hart, 2002; Levenstein, 2001; Moray, 1995, 2000; Silverstein, 2007). To this end it is important that ergonomics begins to build links to debates in the social sciences, as noted by Badham et al (2001). Moray (2000: 858), for example, stated that 'the beginning of a new century is an appropriate moment to consider the role of ergonomics in relation to the problems facing society. To help solve these serious global problems, ergonomics needs to be open to new disciplines, particularly those in the social sciences'.

Ergonomics is inherently bound up with ethical concerns: it is a 'socially situated practice' (Hancock and Szalma, 2004: 501) and, as such, it is intrinsically connected to political debates about the good society, about how we should live. This is a fundamental question for scholarly inquiry - for some, even more important than those addressed by natural sciences (Minogue, 2005). Conflict over ideas about the good society has animated social change throughout history. For this article, questions of design and planning have direct implications for how society is made and remade, to what ends and by what means. Ergonomics, as research and practice, has its part to play in accounts of the good society.

Concern with the good society is not very far-removed from the history of ergonomics (e.g. Hancock and Drury, 2011). Ergonomics was originally concerned with issues of health and safety in the workplace, building on union support to make working life healthier and as free from injury as possible. Issues of health and safety in the workplace are, of course, political issues and connect to debates about a good society (who is made to work and under what conditions?) (Brewer and Hsiang, 2002). Arguments about the good 
society can never be closed or settled, they are always ongoing and a part of social change. Our aim here is modest: to build and defend a particular argument about how we might understand the relationship between ergonomic design and politics and what this, in turn, means for ideas about the good society. In so doing it can help to make concrete Moray's earlier appeal to the discipline to expand its horizons into the social sciences. This may make the boundaries of the discipline appear less sharply defined but for many years the meaning of ergonomics has been increasingly contested (Brewer and Hsiang, 2002: 285; Meister, 2000: 13; Pheasant, 1991). In this respect we are contributing to the reconstitution of the discipline rather than trying to render it indistinct.

The relationship between ergonomics (and by extension design more broadly conceived) and politics is best understood in terms of libertarian and authoritarian approaches to the subject (Ward, 1995: 40). This relationship should be understood as a continuum rather than a binary division. We draw on the work of the British writer Colin Ward who wrote on issues of design, technology and planning for around 50 years up until his death in 2010. Ward is significant because it is his work that helps to clarify the meaning of these two approaches.

The article is organized as follows: it begins with a brief sketch of Colin Ward's work and ideas and their relevance to ergonomic research and practice before setting out the two ends of the spectrum in design between libertarian and authoritarian approaches. We will demonstrate that it is easier and more 'normal' within AngloAmerican ergonomics for more authoritarian approaches to prevail, often against the wishes of designers who have had to fight with their employers for best possible design outcomes. We will illustrate these issues by drawing on debates about the design and manufacture of schoolchildren's furniture. In conclusion we will show why ergonomics would benefit from embracing political and ethical issues in order to stimulate a wider debate amongst its practitioners.

\section{Colin Ward: The Politics of Do-It-Yourself Design and the Good Society}

Colin Ward had an eclectic background dating back to his discharge from the British army at the end of Second World War. Drawn towards anarchism in his social life, he moved into the precarious world of the self-employed, working for architects, educational authorities and town planners, amongst many other relevant occupations (Goodway, 2012). It was out of these experiences that Ward began to develop his distinctive ideas about design and planning that are pertinent to the politics of ergonomics. Ward (1991) claimed no great originality for his work, always citing his major influences: Patrick Geddes, Lewis Mumford, Ebenezer Howard, Peter Kropotkin, William Morris, Walter Segal and countless others. Ward was a synthesizer, looking for ways to root planning and design in the community, whether in 
self-build housing schemes, construction of allotments, workers in factories or community planning activities. As White and Wilbert (2011) note, the social sciences have been interested in issues of design and planning for some time but almost always focus on the role and training of the professional designer. Ward's work focuses on the design practices of lay people. It takes seriously the principle bequeathed by the Arts and Crafts movement that we are all potential designers and creative people, a potentially troubling idea in a world dominated by professions (Ward, 2002).

What, then, does it mean to view the politics of ergonomics and design in terms of libertarian and authoritarian practices? Following the Jewish scholar Martin Buber, Ward (1990: 18) argues that a libertarian understanding of design and planning is rooted in a view of our social instincts which are part of our human nature, what Buber calls the social principle. The social principle is reflected in the normal practices of everyday life and society: mutual aid, self-help, cooperation and solidarity with others. In lectures delivered at the London School of Economics in 1995, Ward articulated the way in which this natural sociability had manifested itself in the everyday practices of working-class communities in Britain prior to the rise of the modern welfare state:

When we compare the Victorian antecedents of our public institutions with the organs of working-class mutual aid in the same period, the very names speak volumes. On the one side the Workhouse, the Poor Law Infirmary, the National Society for the Education for the Poor in Accordance with the Principles of the Established Church; and on the other, the Friendly Society, the Sick Club, The Co-operative Society, the Trade Union. One represents the tradition of fraternal and autonomous associations springing up from below, the other that of authoritarian institutions directed from above. (Ward, 1996: 9)

An authoritarian approach to design has its roots in an alternate view of human nature. Society is something to be controlled by an external agent, reflected in what he (following Buber) called the political principle - ultimately the realm of the state. A different set of values and institutions apply here: hierarchy, the state, authority, domination and power (Ward, 1990). With regard to the way in which the political principle undermines our natural social instincts, Ward observed of the welfare state that was constructed in the UK after 1945 that:

The great tradition of working-class self-help and mutual aid was written off, not just as irrelevant, but as an actual impediment, by the political and professional architects of the welfare state, aspiring to a universal public provision of 
everything for everybody. The contribution that recipients had to make to all this theoretical bounty was ignored as a mere embarrassment - apart, of course, from paying for it. The 19th century working classes, living far below the tax threshold, taxed themselves in pennies every week for the upkeep of their innumerable friendly societies. The 20th century employed workers, as well as its alleged National Insurance contributions, pays a large slice of its income for the support of the state. The socialist ideal was rewritten as a world in which everyone was entitled to everything, but where nobody except the providers had any actual say about anything. (Ward, 1996: 12)

A politics of design should not be understood simply as contrasting political ideologies and the design process, but as a contrast between a more libertarian approach to the practice and a more authoritarian one. And at its heart is the issue of control over decisionmaking about designs for everything from a welfare state to safer working environments (Ward, 2002). Ward noted, for example, that over the course of the 20th century, architects have been subject to the increasing regulation, control and direction of state bureaucracies, whether governed by political parties of the left or the right (Ward, 1996: 11).

Ideas about human nature and its relationship to social forms are, of course, contentious. The models of human behaviour used in ergonomics are themselves based on narrow assumptions about human nature and society, even when writers are sensitive to the complexity of human subjects and social relations (e.g. Göbel and Zschernack, 2012). Ward has cited approvingly a quote from the Russian anarchist Mikhail Bakunin that 'man has two opposed instincts; egoism and sociability. He is both more ferocious in his egoism than the most ferocious beasts and more sociable than the bees and ants' (Suissa, 2005). Egoism is not a negative quality per se but it can lead to antisocial practices and institutions; equally, sociability can lapse into conformism. Achieving a good society always relies on building, adapting and changing institutions and practices to avoid these shortcomings. There can be no fixed or permanent social order in a free society as it will be a society in which people will advance by questioning and improving what has gone before (Ward, 2004).

Thus, repeatedly in his work, Ward tries to highlight countervailing trends that support the values he thinks most important as the basis for a good society: self-help and mutual aid. Often writing with others, including figures such as Peter Hall, former head of the Royal Institute of British Architects, Ward's work (part ethnography and part historical narrative) catalogued everything from designers committed to self-build housing (e.g. Walter Segal); to squatters whose movement in Western Europe in the 1970s helped generate housing cooperatives in many major cities; to the new town movement with its aim to enhance democratic public participation in the 
construction of living environments; and the activities of tenants in rundown housing estates who sought to take them over and transform them, often against the permission of the local council (Ward, 1974a, 1989: 80-82, 1990: 7). Ward's work always stressed the practical aspect of design in everyday life and how people could act individually, with others or with designers committed to public participation, enabling them to design and build the things that they want to see and use. Borrowing from the architect John F. C. Turner, Ward noted that the first principle of housing was 'when dwellers control the major decisions and are free to make their own contribution to the design, construction or management of their housing, both the process and the environment produced stimulate individual and social well-being' (Ward, 1990: 42). Ward's (and Turner's) point is that there is an intimate connection between the means by which you live and work and the type of society you aim to produce. You cannot produce or design a libertarian society by authoritarian means, including bureaucratic managerialism. If you want a more libertarian society you need to build it by acting in accord with those values here and now, hence Ward's emphasis on mutual aid and self-help as the values and practices according to which a good society could be built (Ward, 1985, 1990). He documented how these values and practices could be incorporated into planning and architecture and we suggest that ergonomics should do so as well.

\section{Ergonomics and the Authoritarian Model: Do-It-For-You Design}

Taking Ward's argument about authoritarian approaches seriously means recognizing that he rooted them in a particular mode of thought that was founded on the political principle. Thus for Ward (like Martin Buber) the political is the realm of power, the state, hierarchy, authority and domination. These concepts and the practices they generate are reflected in a number of characteristics that can be associated with a particular approach to ergonomics: a do-it-foryou society in which such decisions are taken, to a greater or lesser degree, by external actors and imposed upon the workforce or other subject groups.

In ergonomics two characteristics reflect this more authoritarian approach to design: professionalism, technical specialization and scientific knowledge; behaviourism, human nature and design. We examine these in turn with examples from debates about the design of schoolchildren's furniture. This raises a number of issues about the relationship between design and health, particularly with regard to the problem of lower back pain - a global 'epidemic' which is increasing (Bendix, 1994; Department of Social and Family Affairs, 2004; Diep, 2003: 4; Milanese and Grimmer, 2004). Ward's two approaches (authoritarian and libertarian) represent tendencies in ergonomics as if they were ideal types, helping us indicate the extent to which a concrete social practice tends towards either one or 
the other approach (Weber, 2011). A designer may move in either direction, depending on the context of their work. Ergonomics has evolved in a way that generates these contradictory practices and forms of knowledge.

In terms of the politics of ergonomics the significance of what Ward calls the libertarian and authoritarian traditions is that they implicitly provide us with an account of what society must be like and indeed, of human nature itself, in order for such approaches to be applicable to the subject at hand. A conception of the good society is implicit in both of these approaches to ergonomics and what we are doing here is rendering these ideas manifest as ideal types.

\section{Professionalism and technical specialization - Science vs lay knowledge}

A key theme in Ward's work is the increasing professionalization of design and with it the increasing dominance of technical knowledge. Professionalization produces an exclusive profession that is controlled by members who have to undertake specific training almost invariably accredited through universities and which is, in turn, sanctioned by the state as the ultimate source of authority. This trend is a commonplace amongst the professions. The problem of professionalization is that it is not simply a neutral scientific training but also a form of social power. No science, including ergonomics, is a politically or socially neutral act (Hancock, 2003: 1010). Ward notes that professionalization has been established in conjunction with increasing bureaucratization of societies (Illich, 2005; Ward, 2002: 19-20). This makes the lay person dependent upon the professional. Ward notes that not only has design become increasingly professionalized and exclusive but that it has also become more narcissistic. As design has become separated from popular control so it has become more insular and self-reverential with the endless proliferation of awards for and by designers. What is 'good design' is determined by the profession more than it is by the end users and their experience of the design (Ward, 2002, 2011a).

Professionalism and technical/specialist knowledge tends to increase separation between designers and end users. Authoritarian practices take control of design and decision-making out of the hands of the end user (worker, consumer) and place them in the hands of the designer and client (employer). The justification for this separation of power and knowledge between lay people and designers lies in the latter's claim to specialist knowledge. The issue is the extent to which specialist knowledge is subject to popular control or whether it asserts power over the end users. This can show up in workplace power struggles over controlling the working environment - a crucial issue for trade unions. It is also part of the reason why ergonomics has received such strong support from trade unions who had hoped that ergonomics would be a means to pressurize employers to supply better and safer working environments. As 
Sagot (2003: 139) notes, in theory, design is meant to be a cooperative process and discourses to this effect can easily be found in ergonomics. In practice, however, the nature of design 'remains subordinate to working conditions'.

Perhaps the most powerful way in which ergonomics knowledge and practice have evolved at the expense of lay knowledge is through the understanding of science in the discipline. Overwhelmingly, ergonomics tends to draw its ideas from anatomy and anthropometrics, biomechanics, kinesiology, engineering, physiology, psychology, mathematics and statistics, with a nod to the behavioural practices of the management sciences (Brewer and Hsiang, 2002: 286; Soares and Rebelo, 2012). Of these, only psychology might connect to the social sciences. Wilpert concluded that 'many if not most products and systems are still designed and manufactured without adequate consideration of human factors', which is not surprising given the strong emphasis on natural over social science in ergonomics (Wilpert, 2008: 19).

Many writers acknowledge, however, that ergonomics is about the way in which people relate to their (working) environment. The consequence of drawing almost exclusively from the natural sciences is to reduce the human being to a variable to be factored into calculations about such things as height, weight, movement, shape, volume, vision, cognitive responses and so on (Wilkin, 2010). The human subject as social actor is largely absent. In the same way the environment within which the human subject is placed is also stripped of its social meaning and organization. This is not to say that natural science is unhelpful or not essential to ergonomics (or to design more generally) but it is to say that the way in which science operates is as a social practice and convention that has profound social consequences in the area of design.

As libertarian critics such as Bakunin warned in the 19th century, science was in grave danger of becoming the new form of absolute knowledge, unchallengeable and beyond the realm of understanding of non-specialists. Even when a natural science fundamentally changes its position on an issue it simply moves from one pole of absolute authority to another. Thus, in relation to this article the ways in which doctors have historically given very bad advice on posture to patients and on how to treat bad backs by remaining bed-bound is a good example (Mandal, 1985: 56). This convention, of course, has been superseded by recognition of the need to keep the body moving. It does not matter which of the two medical answers is ultimately correct. What matters is that they both have the authority of medical science behind them. Thus, in practice, they are both correct. When such knowledge becomes institutionalized in a profession, such as ergonomics, it takes on the appearance of being exclusive, authoritative and unchallengeable. As Ward (2002) notes of the professions, they derive their power from and at the same time support the elites who employ them. 
Ward, following Bakunin, says that this valorization of science has had political consequences for the way in which design is carried out. Ergonomics is driven by the desire for pure technique but can do so only by ignoring the social and political issues raised by its work. Moray (2000: 860) says of his own early experiences working in ergonomics for the National Research Council in the nuclear power industry that certain issues were out of bounds such as 'social and organisational problems'. He goes on to conclude that 'fortunately such attitudes have largely disappeared'. The recent change from the 'Committee on Human Factors' to the 'Committee of Human-Systems Integration' might be taken as indicative of this new trend. ${ }^{1}$

Inevitably, if ergonomics adopts this approach to a science of design it must, by necessity, exclude or limit the significance of lay knowledge when it comes to its major decisions, it must necessarily exclude concerns about the political significance of its work as being beyond the bounds of science. Of course, the reality is that even when adopting such an approach, ergonomics is implicitly presenting an argument about human nature and society. There is no pure technique in the study of human subjects and their environments. Thus, for dominant approaches to ergonomics, human subjects are objects that can be controlled and directed towards particular ends and designs. It is their behaviour that can be changed and their bodies made to fit the design and scientific laws that they generate, a point to which we can now turn.

\section{Behaviourism, human nature and design}

The conception of human subjects that dominates in ergonomics is a rational actor model that claims to have universal characteristics, an actor whose behaviour can be measured, calculated, controlled and modelled in such a way that it produces universal ergonomic knowledge and practices (Dekker, 2011b). Meister (2000: 14) says that the human is the domain of the behavioural and technology the domain of the physical. Even those seeking to open up ergonomic debates still embrace behaviourism as a central principle of the discipline (Brewer and Hsiang, 2002: 286). The dangers of such assumptions about the idea of the human subject as rational actor have been explored in many areas of the social sciences. The rational actor model presents an ahistoric and asocial view of the human subject that reduces the complexity and contingency of human subjects to a deterministic and fatalistic model (Foucault, 2003; Morales and Garcia-Acosta, 2012). In ergonomics it leads to the production of scientific and technical knowledge that is ultimately imposed upon human subjects, no matter how much consultation might take place. It is human behaviour that can be measured in universal terms, according to such modelling, an abstraction that takes concrete form only when being measured (Morales and Garcia-Acosta, 2012). And it is precisely the problems of behaviourism as an approach to the 
human subject that arise here and leads, in theory and practice, to authoritarian conclusions and design practices. If the human subject is viewed in behavioural terms as an object to be altered, amended and controlled by scientific and technical knowledge then its consequences are, in Ward's terms, highly authoritarian. It is the political principle manifest in design whereby an external authority is able to impose its view on subject agents on the basis of power, authority, hierarchy and domination. It is an example of a do-it-for-you approach to design, not do-it-yourself. There is no intrinsic human nature in such assumptions, simply a view of the human subject as a blank slate and endlessly malleable physical object to be controlled and shaped by external forces (Fry, 2011: 29-32). But this is to mistake the physical adaptability of the body for our natures, a contentious assumption at best (Trigg, 1999).

\section{Malleable bodies}

The body is undoubtedly malleable, but this malleability is a highly politicized issue in itself as work on what is called 'body theory' in the social sciences makes clear. For Turner (1996: 21) and Shilling (2005: 21) the body-society relationship is the central concept in sociology and they present a case that says that major political and personal issues are problematized and expressed through the body. Thus, in a study of the production of school furniture, Lane and Richardson (1993) interviewed the world's five leading school furniture companies and asked them what research their designs were based on; the answer was 'none'. Universal assumptions about good school furniture design were a priori assumptions by designers who viewed their market and the human subject in global behavioural terms (Diep, 2003: 12). This follows quite logically from a commitment to viewing the human subject as a unitary, rational actor whose behaviour can be measured and altered in accord with design plans. But what 'body theory' makes clear is that such forms of universal behaviourist knowledge can work in practice precisely because the body can be made to fit or conform to the theoretical claims of the designers, with the ultimate cost borne elsewhere. This scientific knowledge is also a form of social power that, following Foucault (2003; also Fry, 2011), inscribes itself upon the body, altering its shape to conform, in this case, to the needs of the design. But its practices are, in Ward's terms, highly authoritarian.

For example, schoolchildren can be made to fit bad furniture designs, as Mandal (1987) observed in his work on forward-sloping desks and chairs. He goes further and says that authoritarian design assumptions impose themselves upon their subjects and end users. Therefore, the design of school furniture, and indeed of office furniture, that has taken place over the course of the 20th century was not based on research driven by the interests of the end users (schoolchildren and office workers); nor was it based on the practice of consulting the end users or deferring to them on design issues. 
As Chung and Wong (2007) noted in a study of 214 schoolchildren in Hong Kong, almost none had the right chair height. Scientific technical knowledge is itself sufficient for making such decisions and transcending subjective and fallible lay knowledge. Even when schoolchildren attempt to correct these design flaws by shuffling in their uncomfortable seats, rocking backwards and forwards on their chairs to find a better resting point, they are subject to other forms of social power by teachers (or parents if at home) to sit up properly and to stop moving around (Mandal, 1987). This common social convention to impose an ideal form of posture on children (sit up straight, sit still and so on) further enhances the consequences of bad furniture design (Diep, 2003: 10; Knight and Noyes, 1999). The body instinctively and naturally resists the pressures to which it is subjected (Knight and Noyes, 1999: 757; Mandal, 1987; Wilkin 2009).

Social theorist Sarah Nettleton (1998: 6) has written that the more our knowledge of bodies increases, the more we can attempt to control them. This point is echoed by Raymond and Cunliffe (2000: 12) in their work on the modern office where they say that what is needed is a science of worker's needs, so that they can be controlled more. Their point is presented as part of the discourse of a neutral objective behavioural ergonomic science but it is at the same time knowledge that serves the ends of elites, not workers, in this case employers seeking to control a workforce. The point here is not that the designer who utilizes such a behavioural outlook is in some sense a malign agent. Rather, the issue is the nature and control of design practices. This, in turn, promotes an authoritarian relationship whereby the end user is viewed in behaviourist terms as someone or something to be manipulated and controlled. Moray (2000: 866) reflects this point when he says that the role of the ergonomic designer is to give advice on how to change the behaviour of the worker or end user. This is revealing of the professional/technical approach to design that views human subjects in terms of behavioural variables to be manipulated, however benignly. It is, implicitly, an authoritarian approach to ergonomics.

\section{Ergonomics and the Libertarian Model: Do-It-Yourself Design}

Colin Ward's work in design and planning was based on his commitment to self-help and mutual aid, two everyday practices of social life. Control of design was at the heart of good practice. For Ward, the community or workplace was the appropriate place for designs to be discussed, formulated and accepted or rejected. Design was given legitimacy by the extent to which it was controlled by the community or workforce rather than the credentials of the designers or the authority of the state or company to impose it. Ward's (1974b) model of design may be seen as idealistic and indeed he fully respected the work of the utopian socialists in sketching models of a future good 
society based on cooperation and mutual aid. But Ward's work was empirical and realistic too: taking into account the latent and manifest social relations that already structured much of life:

The argument of this book is that an anarchist society, a society which organises itself without authority, is always in existence, like a seed beneath the snow, buried under the weight of the state and its bureaucracy, capitalism and its waste, privilege and its injustices, nationalism and its suicidal loyalties, religious differences and their superstitious separatism ... Of the many possible interpretations of anarchism the one presented here suggests that, far from being a speculative vision of a future society, it is a description of a mode of human organisation, rooted in the experience of everyday life, which operates side by side with, and in spite of, the dominant authoritarian trends of our society. (Ward, 1973: 11)

It reflects the libertarian approach to design and planning that Ward advocates as part of the means for building a good society. Design and the control of design is central to a good society as it entails such things as control of resources, communities and the workplace. Whoever controls these effectively controls the mechanisms that produce and reproduce society. There are two key factors to Ward's libertarian approach to design (i.e. direct action and autonomy) and in setting these out we will illustrate them again with examples from ergonomic work on children's school furniture.

\section{Participative approaches to ergonomics}

Before detailing these two factors, we want to clarify our understanding of important tendencies in the do-it-yourself direction, coalescing around ideas of user-centred, inclusive or participatory design. The ergonomic designer is to cooperate with the workforce or community for whom designs are intended. The practical limitations of this for ergonomics have already been mentioned: in reality design is often constrained by economics and the control of the client so that workers and communities do not exercise the control over their workplaces and technologies that characterize a do-ityourself, libertarian approach.

Noro and Imada (1991) justify and outline a participatory approach to ergonomics in ways that refer to the political principle of social organization. Tellingly, Noro (1991: 22) defines participatory ergonomics 'as ergonomics introduced via small-group activities, semivoluntarily performed by workers with the support of their companies'. His definition clarifies the general tone of his argument in favour of this approach: it is envisaged as a tool that managers and employers should be persuaded to use in cost/benefit exercises. Workers are seen as 'resources' (1991: 3) to be used within a framework built by designers and managers ( $p .4)$ as well as to advance 
ergonomic science (1991: 4). Imada (1991: 31) makes more headway into the do-it-yourself approach; its value, he suggests, resides 'not in the methodology or the tools of participation, but in enabling people to participate in developing, designing, and utilising ergonomics to improve their work'. And, perhaps prefiguring recent concerns (Dekker et al, 2012; Hancock, 2012), he suggests that participatory ergonomics has strong social and political relevance because the involvement of workers in the development and implementation of technologies they use in the workplace is vital for the survival of our society (1991: 32). In fact, participatory ergonomics allows the self-determination of workers, the workers' control over their own technologies and workplaces (1991: 38). This, however, is compromised by an attachment to the logic of organizations. The vocabulary of alienation and workers' control should not be mistaken for a promotion of Marxist or anarchist ideas. On the contrary, Imada argues that workers' alienation from technologies 'has no place in a highly competitive international market-place' (1991: 32) and that the involvement of workers in the development and implementation of technologies and systems fits into the logic of organizations that move away from hierarchical towards flatter or networking structures (1991: 38-41).

These two instances reflect the limitation of user-centred or participatory approaches to ergonomics more widely in that these can easily offer the appearance of empowering a workforce or community whilst in reality subjecting them to external regulation and control and fitting into organizational structures which are far from being controlled by workers who staff them. Libertarian language has become very popular in design debates about public participation. Some have noted that it has become a global trend to encourage the public to participate in the design process (Barnes, 1999; Rowe and Shepherd, 2002). Spinillo and Fujita (2012) have written on the essential qualities of do-it-yourself products in emergency situations in Brazil. However, participation is at best very thin and at worst largely irrelevant to actual outcomes (Barnes, 1999). Ward quotes a television show on the management of the London Zoo where the senior managers were themselves using libertarian language of participation on the part of workers:

For me the most chilling moment in Molly Dineen's brilliant series of BBC2 films on the financial crises of the London Zoo came when interviewing one of the directors. He was full of management speak and explained the necessity for empowerment of the Zoo's workforce. 'Once you've given them empowerment', he said, 'You've got them in the grinder. (Ward, 1996: 77) 
through an attachment to professional judgement. The user-centred approach to design is characteristic of this. It seeks a greater integration of human and design factors by stressing the importance of goals, instruments and people in the use of systems. Yet 'the human', we are told, 'is a critical resource that, if effectively integrated within a system, can greatly enhance the range of coordination between information and action that is possible' (Flach and Dominguez, 1995: 23). This not only betrays a commitment to a form of behaviourism but it also indicates that humans are envisaged as resources used by designers in the development of systems (Wilkin, 2010). Perhaps human users are given more attention than in other approaches, but it remains that workers and communities are nevertheless still deprived of the control over their own work and living environments.

A similar shortcoming is noticeable with the approach known as 'empathic design' (Koskinen et al, 2003). It places understanding users, in their generality and specificity, at the heart of the design process, and this is based on designers' ability to intimately identify with people so as to make design relevant to their desires and needs. This involves studying users in real situations in order to understand from their practices how they interact with design, even to simulate their daily life as in the case of people with sensory impairments (Fulton Suri, 2001, 2003; Koskinen and Battarbee, 2003). Empathy poses a problem to do-it-yourself principles: it translates issues of workers' and communities' control over their environments into deep understanding of subjective and emotional experiences of design. The emphasis on the individual, perhaps due to the roots in psychological theories (Kouprie and Visser, 2009), strips concerns for the good design and good society from any political relevance. Additionally, the efforts designers make to feel the world from the viewpoint of users do not challenge the dominance of professional judgement. Here, too, workers and communities are dispossessed from their autonomy and ability to act without intermediaries.

\section{Direct action and a complex social model}

Direct action is often associated with a form of radical political activity, such as the anti-poll tax campaign, wildcat strikes in the workplace or, more recently, the Occupy Movement. But Ward points out that it has a much broader meaning in libertarian literature. Simply put, it means doing-it-for-yourself; being in direct control over the thing that is being designed (Ward, 2011a, b, c). The virtue of direct action from a design point of view is that it is about the community or workforce exerting their power over the process rather than merely being subject to it.

Despite the above remarks there have been many examples where designers have sought to directly work with communities or workers. Outside the Anglo-American ergonomic tradition this is perhaps more the norm. French approaches to ergonomics are much more concerned with viewing ergonomics as a social practice 
which has to address issues of power and class in the struggle over the design of the workplace. The French approach to ergonomics eschews a commitment to formalism and rational choice models, viewing the workplace as a site of collective activity (Daniellou, 2005). Activity, not behaviour, is the key concept which reflects a very different approach to and understanding of human nature.

Ward's work emphasizes the complex and layered nature of social order. It presents a view of society that avoids the reductionism and determinism associated with the scientific modelling favoured in Anglo-American ergonomics in favour of one that emphasizes the contingent, specific and local nature of knowledge about design needs and practices. Understanding such a social order requires a multidisciplinary approach when it comes to design in order to deal with the complex interactions generated by people in their environment. This persistent theme in Ward's work has begun to find echoes in contemporary ergonomics where debates about complexity theory have emerged in the literature (Dekker, 2005, 2011b). What complexity theory shares with Ward's work is recognition of the problematic assumptions about trying to apply linear causal models to social relations which are emergent, contingent and open to innovation. There can be no simple linear causal relation to be drawn between bad furniture design and lower back pain (Diep, 2003: 17). Such a relationship could only hold under circumstances where all things are equal, an ideal found only in the closed realm of the laboratory. As another example, designers have sought to find ways to measure the rate at which supermarket checkout operators process barcoded items as a means of increasing productivity, or making them work harder. The consequences of this have been to generate repetitive strain injuries in abundance for a workforce that struggles to defend itself from bad design and bad work practice (Hazards, 2005). Nonetheless, it can be argued that on this basis human behaviour is predictable and controllable, it is a closed environment that can be measured, controlled, speeded up and slowed down according to the employers' demands. What it also does is impose authoritarian work practices upon a workforce who have, in turn, to find ways to resist the model and its causal assumptions by enacting go-slows, sabotaging their equipment or organizing a walkout of the job. The closed model of this particular workplace, designed to generate predictive human behaviour, runs into the reality of direct action by a workforce who refuse to work under such conditions. Design inevitably runs into the question of the political, and authoritarian designs often generate libertarian forms of resistance, direct action. Complex social bodies, therefore, require a complex social ontology and view of causality if they are to be properly understood. Lower back pain has several causes but bad furniture and prolonged sitting are certainly among them. Thus, and in line with this, there is evidence to support Mandal's work that under particular circumstances and conditions bad furniture design 
will affect people differentially (Diep, 2003: 16; Kranz, 2000). This has implications for how we think about the relationship between what are often misleadingly called quantitative and qualitative methods (Åsberg et al, 2011). Measurement is needed in design, of course, as in many disciplines, but it is only ever a part of the project and has to be based upon recognition of the contingencies of a complex social ontology (Dekker, 2005).

\section{Self-build and autonomy}

The model of libertarian design principles implicit in the work of Colin Ward places great emphasis upon the idea of self-build design as the action of autonomous agents. Much of the world's housing is vernacular or amateur self-build, as Ward (2002: 11) notes, and of varying skill and quality. It has been historically too. The merit of selfbuild design is that it promotes autonomy and creativity on the part of the agents involved who are able to articulate directly their concerns for the thing to be designed. Even the cathedral at Chartres was the end product of countless builders with no single architect or sovereign designer, out of which emerged one of the world's most beautiful buildings (Ward, 2011d).

Similarly, the participatory ergonomics approach has sought to draw communities, consumers and workers into the design process and taking the example of children's school furniture we can see how this works in practice (Morales and Garcia-Acosta, 2012; Wates, 1999). Mandal (1985) noted in his original research that one of the major problems with the design of school furniture was that it was based on the prejudices of designers and had not arisen out of cooperation or consultation with schoolchildren. As he said, the most revolutionary aspect of his work was that he actually spent time listening to children and taking on board their ideas about what was and was not comfortable. Out of this emerged his idea about the forward-sloping chairs and desks that have begun to spread into school and office furniture, including the reinvention of standing desks. It is possible for those working on such designs to engage meaningfully with their end users in a manner that goes some way towards the principle of self-build. Ward has also written about Port Hawkesbury School in Nova Scotia which was designed by the community working with the designer Stanley King and in which the schoolchildren themselves acted as the architects (Ward, 1995). This successful project was the outcome of a radical rethinking about the relationship between designer and user. Rather than expertise bestowing sovereignty and power on the specialist and over the community, it is simply a form of knowledge at the service of the community. It represents a very different idea of how a profession can function in relationship to both a community and workforce.

Of course this is not a perfect match for the libertarian approach to design that Ward envisages but he was also pragmatic about the possibilities for changing everyday practices, recognizing that 
small adaptations and changes are a part of the movement towards a more fully realized libertarian approach to design and society. In this sense such tendencies are important and to be defended and extended wherever possible. The importance of such approaches is that they help to break down the division between professional and lay person, reconciling scientific knowledge with lay knowledge in the pursuit of meaningfully adequate and practically useful design. When such approaches are not in place the opposite is often the result, and to this end Mandal observes the way in which universal design knowledge about the shape of school furniture produced a sitting posture for school children that no one could actually adopt in comfort for any period of time without it having adverse consequences for their body (Mandal, 1981: 19, 1987; see also Diep, 2003: 10).

The malleability of the body as an unfinished political project emerges here as the consequence of authoritarian design practices and social conventions combining to produce a generation of schoolchildren with bad backs, a problem only reinforced by the general shift in many countries to lifestyles almost entirely geared around work and leisure based on sitting rather than standing (Wilkin, 2009). The problem with this, as Kroemer (1994: 181) says, is that the human body is biomechanically designed for walking around rather than simply sitting down. A life of almost permanent seating is one designed to exacerbate the natural weaknesses and limitations of the spine. There is even plenty of evidence to support the view that mental processes are sharper and more sustained when people are working whilst standing, a practice reflected in the design of offices at the beginning of the 20th century where standing was normal but which fell out of favour as employers sought to find new ways to control their workforce by forcing them to sit instead (Kroemer, 1994; Mandal, 1976: 157; Vercruyssen and Simonton, 1994). In fact, this is often in cheap and poorly designed furniture (Diep, 2003: 11; Vollowitz, 1988). Following the logic of Ward's argument, schools and offices would benefit from more mobile and flexible uses of space and teaching environments both in terms of the physical well-being of the schoolchildren and office workers but also in terms of their mental well-being (Nicholson, 1972; Ward, 1996: 15). The problem here is that in many countries this seems to run up against the logic of school and office design in the 20th century which became sights of social control and authoritarian practice rather than libertarian ones. Encouragingly, there are exceptions to this with Mandal's (1994) furniture design being taken up for schoolchildren in Scandinavian countries.

\section{Conclusion}

In the face of the unsustainable state of the world, what can

political activists and designers do? (Fry, 2011: vii) 
The aim of this article has been to add to and develop the debate that emerged within ergonomics about its relationship to politics. First, taking the work of Colin Ward as its starting point, the article has argued that design and ergonomics are intrinsic to debates about a good society, how we should live and how it should be made. Ward's work provides us with two ideal-type approaches to design which he has written about extensively and describes as libertarian and authoritarian approaches. Second, and as a consequence of the first point, Ward's work alerts us to the fact that the methods and philosophical assumptions (often implicit) about human nature and society involved in the model's generated in ergonomics encourage more authoritarian practices in the Anglo-American tradition. Third, a fundamental problem for Anglo-American ergonomics is that it is built upon a simplified social ontology that fails to pay due regard to the complexity and emergent nature of social relations. As we have shown it presents a picture of human nature and society that is reductive and idealistic; idealistic in the sense that the models that it generates pay little regard to the reality of social life. Rather, reality is expected to conform to the strictures of the models, which means in practice that the body must adapt and conform to the demands of the design.

The advantage of a fuller engagement with the social sciences, as Moray and others have suggested is necessary, is that it will enable ergonomic designers to become more aware of the political implications of their work. This is not to suggest that social science is the realm of enlightened or infallible knowledge. On the contrary, it is replete with disputes over methods and theory as any field of research could be, including its own problematic behaviourist tradition. But it is to make clear that ergonomics is a field of study that has to take account of the social and political context of its practices.

Ward saw his own work in design and planning as being about how people relate to and transform their environment. This is very much in line with ergonomics. But his aim was very different, as this article has shown. It was to provide accounts of the ways in which people are able to make their own designs and transform their own environments in a manner that enables them to control significant aspects of their work or leisure time. Clearly the task of the ergonomic researcher is fraught with difficulties, as many have shown. They work within an environment that they do not control, and which constrains their options and recommendations, often placing productivity before safety (Brewer and Hsiang, 2002: 295). Nonetheless, within that framework there are still choices to be made by the designers as to how they go about their work and how it relates to wider social and political issues. This article aims to inform and develop this aspect of ergonomic research and practice.

\section{Note}

1. We thank an anonymous referee for pointing this out to us. 


\section{References}

Åsberg, R., Hummerdal, D. and Dekker, S. (2011). 'There are no qualitative methods - nor quantitative for that matter: The misleading rhetoric of the qualitative-quantitative debate'. Theoretical Issues in Ergonomics Science, 12(5): 408-415.

Badham, R., Garretty, K. and Kirsch, C. (2001). 'Humanistic redesign and technological politics in organisations'. Journal of Organizational Change Management, 14(1): 50-63.

Barnes, M. (1999). 'Researching public participation'. Local Government Studies, 25(4): 60-75.

Bendix, T. (1994). 'Low back pain and seating'. In Lueder, R. and Noro, K. (eds), Hard Facts about Soft Machines. London, CRC Press, pp. 147-156.

Brewer, J. D. and Hsiang, S. M. (2002). 'The "ergonomics" paradigm: Foundations, challenges and future directions'. Theoretical Issues in Ergonomics Science, 3(3): 285-305.

Chung, J. and Wong, T. (2007). 'Anthropometric evolution for primary school furniture designs'. Ergonomics, 50(3): 323-334.

Daniellou, F. (2005). 'The French-speaking ergonomists approach to work activity'. Theoretical Issues in Ergonomics Science, 6(5): 409-427.

Dekker, S. (2005). 'Past the edge of chaos'. Human Factors and Aerospace Safety. Available at: http://www.lusa.lu.se/upload/ Trafikflyghogskolan/TR2006-03_PastEdgeofChaos.pdf [accessed 10 July 2012].

Dekker, S. (2011a). 'What is rational about killing a patient with an overdose? Enlightenment, continental philosophy and the role of the human subject in system failure'. Ergonomics, 54(8): 679-683.

Dekker, S. (2011b). Drift into Failure: From Hunting Broken Components to Understanding Complex Systems. Farnham: Ashgate Publishing.

Dekker, S., Hancock, P. and Wilkin, P. (2012). 'Ergonomics and sustainability: towards an embrace of complexity and emergence'. Ergonomics, 56(3): 357-364.

Department of Social and Family Affairs (2004). 'Preventing chronic disability form low back pain'. Government of Ireland. Available at: http://www.welfare.ie/EN/Policy/ResearchSurveysAndStatistics/ Documents/renaissance.pdf [accessed July 10 2012].

Diep, N. B. (2003). 'Evaluation of fitness between school furniture and children's body size in two primary schools in Haiphong, Vietnam'. Master's thesis, Department of Human Work Science, Luleå University of Technology. Available at: http://epubl.luth. se/1402-1617/2003/102/LTU-EX-03102-SE.pdf [accessed 10 July 2012].

Flach, J. and Dominguez, C. (1995). 'Use-centered design: integrating the user, instrument, and goal'. Ergonomics in Design, 3: 19-24. 
Foucault, M. (2003). The Birth of the Clinic. London: Routledge.

Fry, T. (2011). Design as Politics. London: Berg Publishers.

Fulton Suri, J. (2001). 'The next 50 years: Future challenges and opportunities for empathy in our science'. Ergonomics, 44(14): 1278-1289.

Fulton Suri, J. (2003). 'Empathic design: informed and inspired by other people's experience'. In Koskinen, I., Mattelmäki, T. and Battarbee, K. (eds), Empathic Design: User Experience in Product Design. [n.p.]: IT Press, pp. 51-57.

Garretty, K. (2004). 'User-centered design and the normative politics of technology'. Science, Technology and Human Values, 29(2): 191-212.

Göbel, M. and Zschernack, S. (2012). 'A systems concept for modelling the ergonomics design process within the product conceptualisation and development frame'. Theoretical Issues in Ergonomics Science, 13(2): 169-186.

Goodway, D. (2012). Anarchist Seeds beneath the Snow. London: PM Press.

Hancock, P. (2012), 'Ergaianomics: The moral obligation and global application of our science'. The Ergonomist, 503(May): 12-14.

Hancock, P. (2003). 'The ergonomics of torture: The moral dimension of evolving human-machine technology'. 2003 Proceedings of the Ergonomics/Human Factors 47th Annual Meeting, Denver, Colorado, 13-17 October. Available at: http://peterhancock.ucf. edu/Downloads/ref_con_pubs/Hancock_2003_2.pdf [accessed 15 October 2013].

Hancock, P. and Drury, C. G. (2011). 'Does human factors/ergonomics contribute to the quality of life?'. Theoretical Issues in Ergonomics Science, 12(5): 416-426.

Hancock, P. and Hart, S. G. (2002). 'Defeating terrorism: What can human factors/ergonomics offer?'. Ergonomics in Design, 2002: ii-xii.

Hancock, P. and Szalma, J. L. (2004). 'On the relevance of qualitative methods for Ergonomics'. Theoretical Issues in Ergonomics Science, 5(6): 499-506.

Hazards (2005). 'Standing problem'. Hazards Magazine, 91. Available at: http://www.hazards.org/standing/ [accessed 13 July 2012].

Illich, I (2005). Disabling Professions. London: Marion Boyers.

Imada, A. S. (1991). 'The rationale and the tools of participatory ergonomics'. In Noro, K. and Imada, A. S. (eds), Participatory Ergonomics. London: Taylor \& Francis, pp. 30-49.

Knight, G. and Noyes, J. (1999). 'Children's behaviour and the design of school furniture'. Ergonomics, 42(5): 747-760.

Koskinen, I. and Battarbee, K. (2003). 'Introduction to user experience and empathic design'. In Koskinen, I., Mattelmäki, T. and Battarbee, K. (eds), Empathic Design: User Experience in Product Design. [n.p.]: IT Press, pp. 37-50. 
Koskinen, I., Mattelmäki, T. and Battarbee, K. (eds) (2003). Empathic Design: User Experience in Product Design. [n.p.]: IT Press.

Kouprie, M. and Visser, F. (2009). 'A framework for empathy in design: stepping into and out of the user's life'. Journal of Engineering Design, 20(5): 437-448.

Kranz, G. The Chair: Rethinking Culture, Body and Design. London, W. W. Norton and Co.

Kroemer, K. H. E. (1994). 'Sitting (or standing?) at the computer workplace'. In Lueder, R. and Noro, K. (eds), Hard Facts About Soft Machines: The Ergonomics of Seating. London: Taylor \& Francis, pp. 181-192.

Lane, K. and Richardson, M. (1993). Human factor engineering and school furniture: a circular odyssey'. Educational Facility Planner, 31(3): 22-23.

Levenstein, C. (2001). 'The politics of ergonomics'. New Solutions: A Journal of Environmental and Occupational Health Policy, 11(2): 89-90.

Mandal, A. C. (1976). 'Work-chair with tilting seat'. Ergonomics, 19(2): 157-164.

Mandal, A. C. (1981). 'The seated-man (Homo sedens) - The seated work position: theory and practise'. Applied Ergonomics, 12(1): 19-26.

Mandal, A. C. (1985). The Seated Man: Homo Sedens. Klampenborg: Dafnia Publications.

Mandal, A. C. (1987). 'The influence of furniture height on back pain'. Behaviour and Information Technology, 6(3): 347-352.

Mandal, A. C. (1994). 'The prevention of back pain in schoolchildren'. In Lueder, R. and Noro, K. (eds), Hard Facts About Soft Machines: The Ergonomics of Seating. London: Taylor \& Francis, pp. 269-278.

Meister, D. (2000). 'Theoretical issues in general and developmental ergonomics'. Theoretical Issues in Ergonomics Science, 1(1): 13-21.

Milanese, S. and Grimmer, K. (2004). 'School furniture and the user population: An anthropometric perspective'. Ergonomics, 47(4): 416-426.

Minogue, K. (2005). The Concept of a University. London: Transaction Publishers.

Morales, K. L. and Garcia-Acosta, G. (2012). 'From "human being" to "social subject": "Unfreezing" ergonomics and the implications for understanding and intervening health-disease process'. Work, 41(1): 3101-3108.

Moray, N. (1995). 'Ergonomics and the global problems of the twenty-first century'. Ergonomics, 38(8): 1691-1707.

Moray, N. (2000). 'Culture, politics and ergonomics'. Ergonomics, 43(7): 858-868.

Nettleton, S. and Watson, J. (eds) (1998). The Body in Everyday Life. London: Routledge. 
Nicholson, S. (1972). 'The theory of loose parts: An important principle for design methodology'. Studies in Design Education Craft \& Technology, 4(2): 5-14.

Noro, K. (1991). 'Concepts, methods and people'. In Noro, K. and Imada, A. S. (eds), Participatory Ergonomics. London, Taylor \& Francis, pp. 3-29.

Noro, K. and Imada, A. S. (eds) (1991). Participatory Ergonomics, London, Taylor \& Francis.

Pheasant, S. (1991). Ergonomics, Work and Health. London: Macmillan Press.

Raymond, S. and Cunliffe, R. (2000). Tomorrow's Office: Creating Effective and Humane Interiors. London: Taylor \& Francis.

Rowe, R. and Shepherd, M. (2002). 'Public participation in the new NHS: No closer to citizen's control'. Social Policy and Administration, 36(3): 275-290.

Sagot, J.-C. (2003). 'Ergonomics in product design: Safety factor'. Safety Science, 41: 137-154.

Shilling, C. (2005). The Body in Culture, Technology and Society. London: Sage.

Silverstein, M. (2007). 'Ergonomics and regulatory politics: The Washington State case'. American Journal of Industrial Medicine, 50(5): 391-401.

Soares, M. and Rebelo, F. (2012). 'Ergonomics in design: Solutions and proposals for better interface with the user'. Theoretical Issues in Ergonomics Science, 13(1): 1-3.

Spinillo, C. G. and Fujita, P. (2012). 'Do-it-yourself (DIY) furniture for emergency situations: A study on assembling a cardboard bench in Brazil'. Theoretical Issues in Ergonomics Science, 13(1): 121-134.

Suissa, J. (2005). 'Anarchy in the classroom'. Available at: http:// newhumanist.org.uk/1288/anarchy-in-the-classroom [accessed 16 November 2012].

Trigg, R. (1999). Ideas of Human Nature. London: Wiley-Blackwell.

Turner, B. (1996). The Body and Society. London: Sage.

Vercruyssen, M. and Simonton, K. (1994). 'Effects of posture on mental performance'. In Lueder, R. and Noro, K. (eds), Hard Facts About Soft Machines: The Ergonomics of Seating. London: Taylor \& Francis, pp. 119-132.

Vollowitz, E. (1988). 'Furniture prescription for the conservative management of low-back pain'. Topics in Acute Care and Trauma Rehabilitation, 2(4): 18-37.

Ward, C. (1973). Anarchy in Action. London: Freedom Press.

Ward, C. (1974a). Tenants Take Over. London: The Architectural Press.

Ward, C. (1974b). Utopia. London: Penguin Books.

Ward, C. (1985). When We Build Again - Let's Have Housing That Works. London: Pluto Press. 
Ward, C. (1989). Welcome, Thinner City. London: Bedford Square Press.

Ward, C. (1990). Talking Houses. London: Freedom Press.

Ward, C. (1991). Influences: Voices of Creative Dissent. Hartland: Green Books.

Ward, C. (1995). Talking Schools. London: Freedom Press.

Ward, C. (2002). Talking to Architects. London: Freedom Press.

Ward, C. (2004). Anarchism. Oxford: Oxford University Press.

Ward, C. (2011a). 'The future of the design professions'. In Wilbert, C. and White, D. F. (eds), The Colin Ward Reader: Autonomy, Solidarity, Possibility. Edinburgh: AK Press, pp. 110-125.

Ward, C. (2011b). 'The State'. In Wilbert, C. and White, D. F. (eds), The Colin Ward Reader: Autonomy, Solidarity, Possibility, Edinburgh: AK Press, pp. 88-108.

Ward, C. (2011c). 'Self-help and mutual aid: The stolen vocabulary'. In Wilbert, C. and White, D. F. (eds), The Colin Ward Reader: Autonomy, Solidarity, Possibility. Edinburgh: AK Press, pp. 210-235.

Ward, C. (2011d). 'Chartres'. In Wilbert, C. and White, D. F. (eds), The Colin Ward Reader: Autonomy, Solidarity, Possibility, Edinburgh: AK Press, pp. 184-199.

Wates, N. (1999). The Community Planning Handbook. London: Routledge.

Weber, M. (2011). Methodology of Social Sciences. New York: Transaction Publishers.

Wilbert, C. and White, D. F. (eds) (2011). The Colin Ward Reader: Autonomy, Solidarity, Possibility. Edinburgh: AK Press.

Wilkin, P. (2009). 'Are you sitting comfortably? The political economy of the body'. Sociology of Health \& Illness, 31(1): 1-154.

Wilkin, P. (2010). 'The ideology of ergonomics'. Theoretical Issues in Ergonomics, 11(3): 230-244.

Wilpert, B. (2008). 'Psychology and human factors engineering'. Cognition, Technology and Work, 10(1): 15-21.

\section{Acknowledgements}

We would like to thank the anonymous referees for their encouragements and comments on an earlier version of this paper.

\section{Biographies}

Dr Carole Boudeau (PhD Brunel University, 2009) is a research fellow in the Health and Care Infrastructure Research and Innovation Centre (HaClRIC) at the University of Reading, UK. Her work currently focuses on design practices in the context of the healthcare built environment.

Dr Peter Wilkin (PhD Southampton University, 1995) is a reader in Social Science at Brunel University since 2004. Prior to that he spent 10 years in the Department of Politics and International Relations 
at Lancaster University. His work has focused on, amongst other things, issues to do with design and the body as well as the philosophy and history of the social sciences.

Professor Sidney Dekker (PhD Ohio State, 1996) is professor in the School of Humanities at Griffith University, Brisbane, Australia. Previously at Lund University in Sweden, he has lived and worked in seven countries, is author of several bestselling books on human error and system safety and has recently been flying the Boeing 737 part-time as airline pilot.

\section{Addresses for Correspondence}

Dr Carole Boudeau, HaClRIC, School of Construction Management \& Engineering, URS Building, Whiteknights, University of Reading, PO Box 129, Reading RG6 6AW, UK.

Tel: +44 (0)118378 7176

Fax: $+44(0) 1189313856$

Email: carole.boudeau@hotmail.co.uk

Dr Peter Wilkin, Department of Sociology and Communication, Brunel University, Uxbridge UB8 3PH, UK.

Tel: +44 (0)1895 267241

Fax: +44 (0)1895 269786

Email: peter.wilkin@brunel.ac.uk

Professor Sidney Dekker, School of Humanities, Griffith University, 170 Kessels Road, Brisbane, QLD 4111, Australia.

Tel: $+61(0) 737354842$

Fax: +61 (0)7 37357730

Email: s.dekker@griffith.edu.au 